\title{
Prolyl-tRNA synthetase from Thermus thermophilus is eukaryotic-like but aminoacylates prokaryotic tRNA ${ }^{\text {Pro }}$
}

\author{
A. D. Yaremchuk ${ }^{1,2}$, K. S. Boyarshin ${ }^{1}$ M. A. Tukalo ${ }^{1,2}$ \\ ${ }^{1}$ State Key Laboratory of Molecular and Cellular Biology, Institute of Molecular Biology and Genetics, NAS of Ukraine \\ 150, Akademika Zabolotnoho Str., Kyiv, Ukraine, 03680 \\ ${ }^{2}$ EMBL Grenoble Outstation \\ 6, rue Jules Horowitz, 38042 Grenoble Cedex 9, France \\ mtukalo@imbg.org.ua
}

\begin{abstract}
Aim. Cloning, sequencing and expression of the gene encoding prolyl-tRNA synthetase, a class IIa enzyme, from the extreme thermophile T. thermophilus HB8 (ProRSTT). Methods. Search for the ProRSTT gene was performed by Southern blot hybridization with chromosomal DNA, the digoxigenin-labeled PCR fragments of DNA being used as a probe. Results. The gene of T. thermophilus HB8 ProRS has been cloned and sequenced. The predicted 477-amino acid protein is significantly more similar in sequence to eukaryotic and archaeal than to eubacterial ProRS. Sequence analysis shows two distinct structural groups of ProRS which most likely had diverged early in evolution: (1) eukaryotic/archaeal group characterized by the absence of an insertion domain between motifs 2 and 3 and by the presence of an extra C-terminal domain beyond the normal class IIa anticodon binding domain; and (2) prokaryotic with a very large insertion between motif 2 and 3 and no extra C-terminal domain. Conclusions. T. thermophilus proS gene was overexpressed in Escherichia coli and overproduced ProRSTT was purified to high homogeneity. In spite of its eukaryotic-like features, T. thermophilus ProRS exhibited highly specific cross-species aminoacylation. The charging ability of the ProRSTT is restricted to prokaryotic tRNA ${ }^{\text {Pro }}$.
\end{abstract}

Keywords: prolyl-tRNA synthetase from Thermus thermophilus, proS gene, cloning, sequencing, expression.

Introduction. Aminoacyl-tRNA synthetases (aaRSs) play a crucial role in the translation of the genetic code in all living organisms. The fidelity of protein synthesis depends to a large extent on the high specificity with which aaRSs charge their cognate tRNAs with the correct amino acid. In spite of the universality of the genetic code, there are barriers to aminoacylation across taxonomic domains that need the tRNA-synthetase coadaptation during the evolution. The adaptations made by aaRSs are sometime correlated with changes in the architecture and/or sequence, which are specific for a certain group of organisms [1,2].

The aaRSs are divided into two quite distinct classes (class I and class II) on the basis of primary structure and the fold of catalytic domain [3, 4]. Class IIa prolyl-tRNA synthetase exists in several distinct archi-

(C) Institute of Molecular Biology and Genetics, NAS of Ukraine, 2012 tectures in different organisms. There are basically two distinct types of ProRS, each with two variants. The first is the eukaryotic-like type, characterized by a unique $\mathrm{C}$-terminal domain. The second is the prokaryoticlike enzyme, lacking this domain $[5,6]$. Each of these two types is recognizable by specific sequence characteristics which even extend to the residues in the catalytic domain. Both types share a common anticodon binding domain characteristic of class IIa synthetases. At another level of organization, a key difference is the existence and position of a unique editing domain (of about 180 residues) that has been shown to be responsible for hydrolyzing mischarged alanine [7, 8]. In higher eukaryotes and some bacteria there is no editing domain, although the genes encoding a separate editing-like domain, denoted ProX, have been identified (e. g. in mouse, human, Clostridium sticklandii). In lower eukaryotes (e. g. malaria, trypanosome, yeast), the editing do- 
main is found as an N-terminal extension. In the prokaryote-like systems, there is generally an editing domain inserted into the catalytic domain (most bacteria, e. g. Escherichia coli, Mycobacterium tuberculosis, Enterococcus faecium), but some bacteria (e. g. Rhodopseudomonas palustris, Wolbachia) and putative mitochondrial ProRS (e. g. human) have prokaryotic-like ProRS with the lack of insertion domain. In some systems a separate gene encoding an editing-like domain has been identified (ProX or YbaK) and their capability to edit the mischarged alanyl-tRNA ${ }^{\text {Pro }}$ in trans has been shown [8]. The investigation of tRNA ${ }^{\text {Pro }}$ recognition by the $E$. coli and human enzymes has also provided evidences of the divergent adaptation between tRNA and synthetase [9, 10]. Prokaryotic-like ProRS generally recognize A73 and G72 of acceptor stem of tRNA ${ }^{\text {Pro }}$. On the other hand, in eukarya all cytoplasmic tRNA ${ }^{\text {Pro }}$ sequences have $\mathrm{C} 73$ and $\mathrm{C} 72$ and other determinants for recognition, for example by the human enzyme, which are located only in the anticodon. To understand the structural basis for tRNA ${ }^{\text {Pro }}$ recognition and amino acid specificity of the different ProRS types, intensive structural work was done. T. thermophilus ProRS has been crystallized [11] and its structure has been determined at $2.43 \mathrm{C}$ resolution, the first reported structure of ProRS $[5,6]$. We have also crystallized the ProRStRNA $^{\text {Pro }}$ complex [12] and have solved its structure [5, $6,13]$. Recently we have solved the structure of prokaryotic ProRS from E. faecalis [14]. The active site of prokaryotic-like ProRS of the pathogenic bacteria has an open conformation, while the active site of ProRS from $T$. thermophilus is more compact. Thus, the essential differences in the structures of these enzymes can be considered as start point for successful development of drugs that would selectively inhibit pathogenic bacteria, without side effects for the host human organism. Therefore, we cloned the proS gene of $T$. thermophilus as a part of structural and functional study on ProRSs. Here we report the cloning, sequencing and sequence analysis and aminoacylation activity of the recombinant T. thermophilus prolyl-tRNA synthetase using tRNA ${ }^{\text {Pro }}$ from different sources.

Materials and methods. Purification of prolyltRNA synthetase from T. thermophilus and Activity Assays. T. thermophilus HB8 was grown in 300-liters fermenter at $76^{\circ} \mathrm{C}$ as described by Oshima and Imahori
[15]. The cells were harvested by centrifugation and broken with a Franch press. The enzyme was purified from the cell extract by successive chromatography on DEAE-Sepharose, Toyoperl HW-65, hydroxyapatite, and heparin-Sepharose column [11]. Approximately $30 \mathrm{mg}$ of prolyl-tRNA synthetase from $1 \mathrm{~kg}$ of $T$. thermophilus cells were obtained. As judged by sodium dodecyl sulfate (SDS)-PAGE analysis, the purified enzyme was at least $95 \%$ homogeneous.

The aminoacylation reaction proceeded at 37 or $60{ }^{\circ} \mathrm{C}$, respectively, in 501 reaction mixture containing $100 \mathrm{mM}$ Tris- $\mathrm{HCl}(\mathrm{pH}$ 7.9), $10 \mathrm{mM}$ magnesium chloride, $2.5 \mathrm{mM}$ ATP, $2 \mathrm{mg} / \mathrm{ml}$ unfractionated $E$. coli tRNA («Boehringer Mannheim», Germany), $20 \mathrm{M}$ $\mathrm{L}-\left[{ }^{14} \mathrm{C}\right]$ proline $(330 \mathrm{mCi} / \mathrm{mmol}$, «Amersham», USA) and a suitable amount of enzyme.

$N$-terminal and internal amino acid sequence analysis. The amino acid sequences of the N-terminal peptide and five internal peptides of purified T. thermophilus prolyl-tRNA synthetase were determined by the Protein and Peptide Group at EMBL, Heidelberg, by microsequencing.

Two peptides: KETGVQNAYFP and RAPIQVVI, were used to design oligonucleotides which were purched from Genosys.

Recombinant DNA techniques, Southern hybridization, construction and screeening of the genomic library. General recombinant DNA methods were performed according to Sambrook et al. [16]. Genomic DNA from $T$. thermophilus HB8 was prepared by the method of Marmur [17]. Degenerate oligonucleotides oligo 1 and oligo 2, were designed on the basis of amino acid sequence of two internal peptides, according to the preferential codon usage of T. thermophilus. Oligo 1: 5'-ACSGGSGTSCAGAACGCSTACTT-3'; oligo 2: 5'GATSACSACCTGRATSGGSGC-3' ( $\mathrm{S}=\mathrm{C}$ or G; R = $=\mathrm{A}$ or $\mathrm{G}$ ). These two oligos were used as primers in PCR experiment with $1 \mathrm{~g}$ of genomic DNA in100 1 mixture containing $50 \mathrm{mM}$ Tris- $\mathrm{HCl}$ buffer $(\mathrm{pH} 9.0), 20 \mathrm{mM}$ $\left(\mathrm{NH}_{4}\right)_{2} \mathrm{SO}_{4}, 0.2 \mathrm{mM}$ dNTP and 2.5 U Tub DNA polymerase («Amersham»). The amplification was performed under the following conditions: 4 min at $95^{\circ} \mathrm{C}$; 35 cycles of $1 \mathrm{~min}$ at $95^{\circ} \mathrm{C}, 2 \mathrm{~min}$ at $52^{\circ} \mathrm{C}$ and $2 \mathrm{~min}$ at $72{ }^{\circ} \mathrm{C}$. The product was analyzed on $1 \%$ agarose gel and subsequently cloned into the PCR II vector («Invitrogen», USA). This PCR product was labelled using the digoxi- 
genin DNA labelling kit («Boehringer Mannheim») and used as probe for Southern blotting and colony hybridization. The genomic minilibrary was constructed by ligation of a BamHI digest of chromosomal DNA in pUC19 after linearization by BamHI digestion and dephosphorylation. DH5 $\alpha$ was used as E. coli host for screening of the T. thermophilus proS gene.

DNA sequencing. PCR fragments and the chromosomal DNA subcloned fragments were sequenced by the dideoxynucleotide chain-termination method [18] using $\left[{ }^{35} \mathrm{~S}\right]$-dATP or $\left[{ }^{35} \mathrm{~S}\right]$-dCTP (ICN), the Sequenase version 2.0 DNA sequencing kit (USB) and Thermo Sequenase cycle sequencing kit («Amersham»).

Overexpression of T. thermophilus prolyl-tRNA synthetase in E. coli and purification of recombinant enzy$m e$. For overexpression of the T. thermophilus prolyltRNA synthetase in $E$. coli the $p E T 17 b$ vector was used. The coding region of the $p r o S$ gene was amplified from the genomic clone in 30 cycle PCR using Tub polymerase at the annealing temperature of $58{ }^{\circ} \mathrm{C}$ with oligonucleotides 3 and 4 , which contain the recognition sites for NdeI and BamHI, respectively. Oligo 3: 5'-CATAT GGC-GAAGGAGAGAAGGGCCTAACCC-3'; oligo 4: 5'-GGATCCTATTAGTA-CGCCTTGGCGAAGA CCACCG-3'. The PCR product was firstly cloned into the PCR II vector and then subcloned into $p E T 17 b$. Finaly, the 1279 bp KpnI-DraIII fragment of a resulting vector was replaced by chromosomal KpnI-DraIII fargment of $T$. thermophilus proS gene.

E. coli BL21(DE3)pLysS cells carrying the recombinant plasmid were grown at $37^{\circ} \mathrm{C}$ in 6 liters of LB medium containing $100 \mathrm{~g} / \mathrm{ml}$ ampicillin. When the A600 of the culture reached the value of 0.8 , expression was induced by the addition of $0.5 \mathrm{mM}$ IPTG (isopropyl- $\beta$-D1-thiogalactopyranoside). The cells were harvested $4 \mathrm{~h}$ after induction. The pellet of cells was resuspended in $420 \mathrm{ml}$ of lysis buffer (50 mM Tris- $\mathrm{HCl}$ (pH 8.0), $5 \mathrm{mM}$ EDTA, $10 \mathrm{mM}$ 2-mercaptoethanol and $4 \%$ (v/v) glycerol) and cells were disrupted by freezing/defreezing method. Then $4.2 \mathrm{ml}$ of $1 \mathrm{M} \mathrm{MgCl}_{2}$ and $5000 \mathrm{U}$ of DNaseI («Boehringer Mannheim») was added to the mixture and incubated $25 \mathrm{~min}$ at $37^{\circ} \mathrm{C}$. Cell debris was removed by centrifugation ( $20 \mathrm{~min}, 13,000 \mathrm{~g}$ ). The supernatant was heated at $70{ }^{\circ} \mathrm{C}$ for $40 \mathrm{~min}$ and centrifuged at $13,000 \mathrm{~g}$ for $30 \mathrm{~min}$. Then the supernatant was dialyzed overnight against buffer A (20 mM Tris-HCl, pH 7.9,
$5 \mathrm{mM} \mathrm{MgCl} \mathrm{Mg}_{2}, 0.1 \mathrm{mM}$ PMSF, $1 \mathrm{mM}$ dithiothreitol and $0.1 \mathrm{mM} \mathrm{NaN}_{3}$ ) before application on DEAE-Sepharose column $(2.6 \times 25 \mathrm{~cm})$, equilibrated with the same buffer. Protein was eluted with 11 of linear gradient from 0.03 to $0.3 \mathrm{M}$ sodium chloride in buffer $\mathrm{A}$. The active fractions were collected, dialyzed, and chromatographed on heparin-Sepharose column $(1.2 \times 37 \mathrm{~cm})$. The column was developed with a linear gradient of 0 $0.25 \mathrm{M} \mathrm{KCl}$ in 0.51 buffer A.

Results and discussion. Cloning and sequencing of proS gene. For further study on the structure-function relationships of ProRSTT we cloned the corresponding structural gene. The purified enzyme from $T$. thermophilus cells provided several short peptide sequences: $\mathrm{N}$-terminal sequence of 20 residues and 5 internal tryptic peptides. Using sequence information from two peptides, the oligonucleotide primers were designed which allowed PCR amplification of a partial gene fragment (700 bp) of ProRSTT. The correspondence of this fragment to a putative $p r o S$ gene was verified by DNA sequencing. The PCR fragment was labelled with digoxigenin and then used as a probe for Southern blot hybridization to $T$. thermophilus chromosomal DNA digested with several restriction enzymes (Fig. 1, A). The probe was hybridized to the BamHI fargment of about $2.75 \mathrm{~kb}$ (Fig. 1, B). This $2.75 \mathrm{~kb}$ BamHI was cloned into the $p U C 19$ plasmid. The positive clones were identified by colony hybridization and sequenced.

Analysis of the nucleotide sequence of proS gene and amino acid sequence of its product. The nucleotide sequence of $1900 \mathrm{bp}$ DNA fragment containing the T. thermophilus proS gene was determined on the both strands. The open reading frame of this gene contains $1431 \mathrm{bp}$, from which the 477 amino acid residues protein was deduced (Fig. 2). The calculated relative molecular mass of this protein is $54453 \mathrm{Da}$. This is close to the value of $54 \mathrm{kDa}$ estimated by SDS/PAGE and in agreement with the value of $110 \mathrm{kDa}$ estimated by gradient PAGE under non-denaturing condition for the purified enzyme from $T$. thermophilus cells, taking into account a dimeric structure of ProRS. The aminoterminal sequence and five peptides were identical to those determined by amino acid sequencing, showing unambiguously that the correct gene has been identified (Fig. 2).

Comparison of the amino acid composition of the thermophilic and mesophilic, E. coli ProRS shows a 


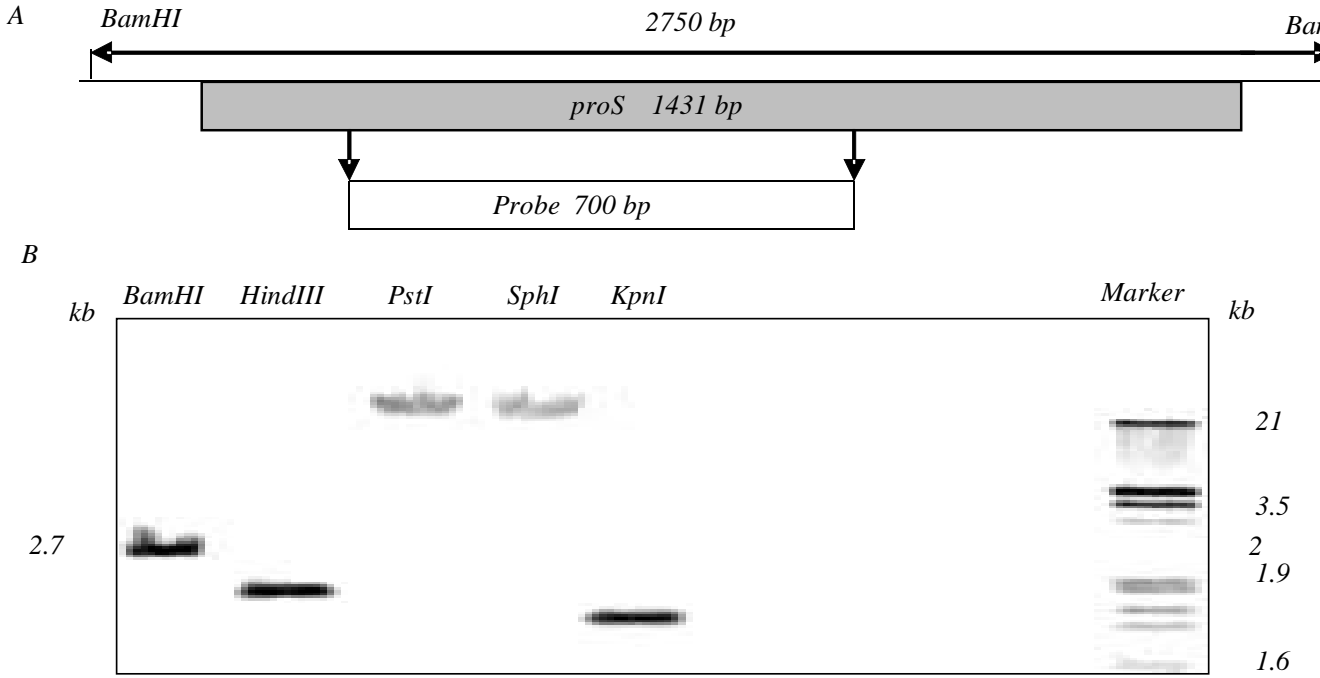

MAKEKGLTPQSQDFSEWYLEVIQKAELADYGPVRGTIVVRPYGYAIWENI 50 QQVLDRMFKETGHQNAYFPLF IPMSF LRKEAEHVEGFSPELAVVTHAGGE 100 ELEEP LAVRP T SETVIGYMWSKWIRSWRD LP QLLNQWGNVVRWEMRTRPF 150 LRTSEFLWQEGHTAHATREEAEEEVRRMLSIYARLAREYAAIPVIEGLKT 200 EKEKFAGAVYTTT IEALMKDGKALQAGTS HYLGENFARAFD IKFQDRDLQ 250 VKYVHTTSWGLSWRFIGAIIMTHGDDRGLVLPPRLAP IQVVIVP IYKDES 300 RERVLEAAQGLRQALLAQGLRVHLDDRDQHTPGYKFHEWELKGVPFRVEL 350 GPKDLEGGQAVLASRLGGKETLPLAALPEALPGKLDAFHEELYRRALAFR 400 EDHTRKVDTYEAFKEAVQEGFALAFHCGDKACERLIQEETTATTRCVPFE 450 AEP EEGFCVRCGRP SAYGKRVVFAKAY
Fig. 1. Cloning of T. thermophilus proS gene: $A$ - schematic presentation of the BamHI fragment of T. thermophilus chromosomal DNA which covers the entire gene sequence of ProRS and the probe, which was used to search for this gene; $B$ - Southern blot hybridization of the T. thermophilus HB8 chromosomal DNA with 700-bp PCR fragment as a probe

Fig. 2. The amino acid sequence of ProRSTT deduced from the nucleotide sequence of the pros gene. The amino acids underlined correspond to the peptide sequences determined by protein sequencing decrease in asparagine, serine, methionine and isoleucine, and an increase in cysteine, tryptophan and histidine in content of the thermophilic protein [19]. Concerning cysteine, it appears 3 times more frequently in the E. coli proteins than in Thermus proteins [19]. But in the case of ProRS only one cysteine is present in the $E$. coli enzyme whereas 5 cysteines were found in $T$. thermophilus enzyme. All these cysteines are located in the C-terminal domain of $T$. thermophils ProRS and as can be seen from the crystal structure of ProRSTT, four of them form a tetrahedral binding site for zinc ion [6]. The analysis of the frequency of the codons shows a pronounced preference for codons possessing $\mathrm{G}$ or $\mathrm{C}$ at the third position. It is as high as $94 \%$, which is similar to that in other Thermus genes [20].

The amino acid sequence of $T$. thermophilus prolyl-tRNA synthetase appears eukaryote-like. Comparison of the amino acid sequence of ProRSTT with all other known ProRSs surprisingly shows significantly more similarity to the enzymes from the cytoplasm of eukaryotes (e. g. $35 \%$ homology to the yeast ProRS and $37 \%$ to the Drosophila melanogaster and human
ProRS) than to eubacterial ProRSs (18\% homology to the E. coli ProRS and $14 \%$ to the Chlamydia trachomatis ProRS). Phylogenetic analysis confirms the fact that there are two distinct structural groups of ProRS (Fig. 3). The first group is eukaryotic/archeal-like including ProRS from cytoplasm of eukaryotes, Mycoplasma genitalium, Metanococcus jannaschii (archae) and $T$. thermophilus, characterised by the absence of an insertion domain between motifs 2 and 3 and by the presence of an extra $\mathrm{C}$-terminal domain beyond the normal class IIa anticodon binding domain. The second group is prokaryotic-like including ProRS from mitochondria of eukaryotes, E. coli and C. trachomatis, which have a very large insertion between motifs 2 and 3 and no extra C-terminal domain. These two forms had diverged early from a primitive ancestor of ProRS. ProRS represents the third $T$. thermophilus synthetase (in addition to GlyRS and IleRS) $[1,21]$ which has eukaryotic/archeal-like characteristics rather than prokaryotic-like, suggesting some possible horizontal gene transfer event.

T. thermophilus prolyl-tRNA synthetase aminoacylates $t R N A$ from E. coli but not from yeast and bovine 


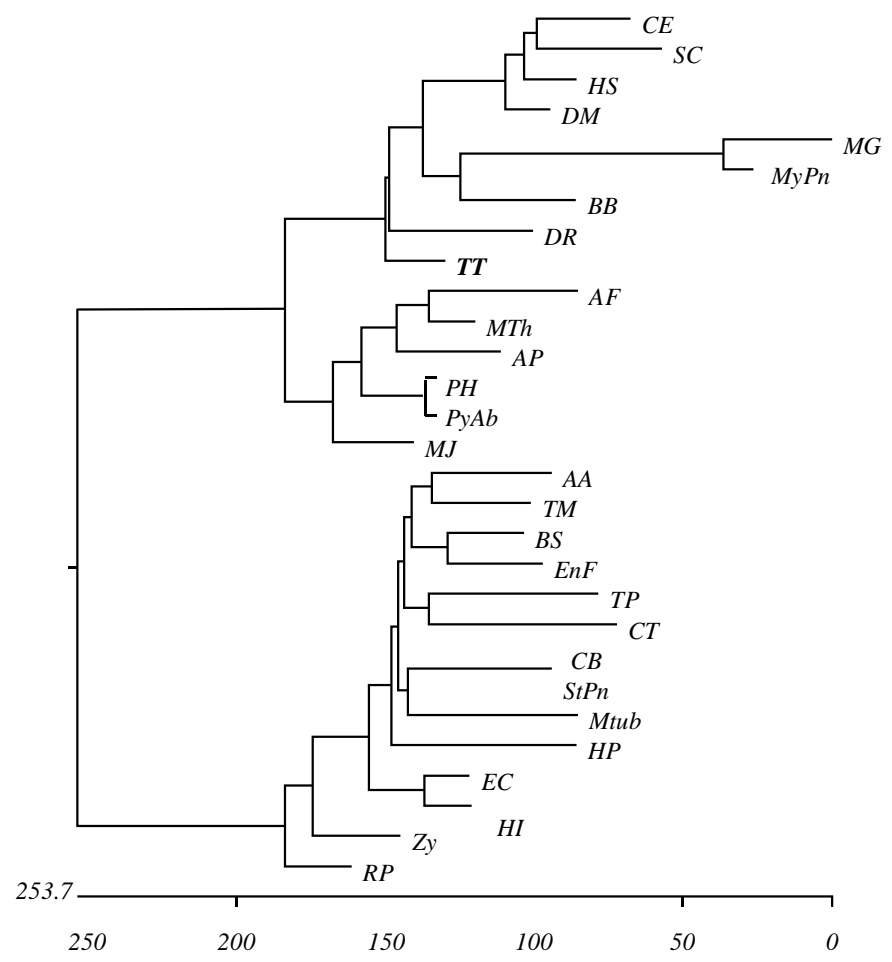

Fig. 3. Phylogenetic tree of ProRS sequences. The tree was rooted between the Bacteria and the Archaea plus Eukarya. Abbreviations: AA - Aquifex aeolicus; AP-Aeropyrum pernix; AF-Archaeoglobus fulgidus; BB-Borrelia burgdorferi; BS-Bacillus subtilis;

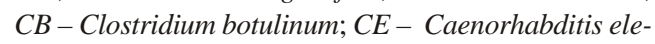
gans; CT-Chlamydia trachomatis; DM-Drosophila melanogaster; DR - Deinococcus radiodurans; ECEscherichia coli; EnF - Enterococcus faecalis; HI Haemophilus influenzae; HP - Helicobacter pylori; HS - Homo sapiens; MJ-Methanocaldococcus jannaschii; MyPn - Mycoplasma pneumoniae; Mtub - Mycobacte ium tuberculosis; MTH - Methanobacterium thermoautotrophicum; MG - Mycoplasma genitalium; PH - Pyrococcus horikoshii; PyAb-Pyrococcus albia; RP - Rickettsia prowazekii; SC-Saccharomyces cerevisiae; StPn - Streptococcus pneumoniae; TMThermotoga maritima; TP - Treponema pallidum; TT Thermus thermophilus; Zy-Zymomonas mobilis. The tree was generated using MegAlign with version 5.1 of DNA STAR package programs. The length of each pair of branches represents the distance between sequence pairs, while the units at the bottom of the tree indicate the number of substitution events liver. To overexpress the ProRS from T. thermophilus in $E$. coli cells, the proS gene was cloned between NdeI and $B a m H I$ sites of the $p E T 17 b$ vector (see the Materials and methods). The overexpressed ProRSTT was purified by heat treatment of the crude cellular extract followed by ion-exchange chromatographies on DEAE-Sepharose and heparin-sepharose. SDS/PAGE analysis of the purified recombinant ProRSTT revealed a band (more than $98 \%$ of purity) with molecular weight of $54 \mathrm{kDa}$, which is consistent with molecular weight expected from the deduced amino acid ProRSTT sequence and exactly corresponds to molecular weight of the enzyme purified from $T$. thermophilus cells.

Due to the fact that $T$. thermophilus ProRS resembles eukaryotic synthetases, one can expected that it might charge eukaryotic tRNA. We tested this suggestion by in vitro aminoacylation of total tRNA from $T$. thermophilus, E. coli, yeast and bovine liver by ProRSTT. Fig. 4 shows that $E$. coli and $T$. hermophilus tRNAs are aminoacylated by ProRSTT with the same efficiency. At the same time eukaryotic yeast and bovine tRNAs are very poor substrates for the $T$. thermophilus enzyme. Eubacterial (E. coli) ProRS recognizes the identity determinants of tRNA ${ }^{\text {Pro }}$ at the acceptor stem and anticodon loop [9]. The primary structures of two isoacceptor forms of tRNA ${ }^{\text {Pro }}$ from T. thermophilus, determined in our laboratory, have revealed the same determinants in the acceptor stem as in case of E. coli tRNA ${ }^{\text {Pro }}$ [22]. They have A73 and G72 instead of C73 and C72 present in the structure of the acceptor stem of eukaryotic

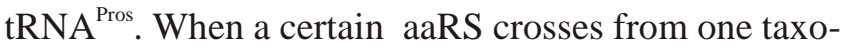
nomic domain to another it has to adapt to a new tRNA sequence. ProRSTT provides interesting example of adaptation which differs from known in the literature. For example, it has been reported that the eukaryoticlike bacterial $T$. thermophilus glycyl-tRNA synthetase is able to charge U73-containing bacterial tRNA ${ }^{\text {Giys }}$, but the enzyme could also efficiently aminoacylate yeast tRNA $^{\text {Gly }}$ containing A73 [1]. Thus, this eukaryotic-like bacterial enzyme adapted to prokaryotic tRNA without losing capacity to charge the eukaryotic one (as result of lacking sensitivity to N73). The case of co-adaptation of ProRSTT is more complicated and probably affected other parts of tRNA in addition to the acceptor stem. Although the structure of ProRSTT complexed with tRNA ${ }^{\text {Pro }}$ was solved by us, the tRNA acceptor stem appeared not to be ordered [5,6], and therefore, the structural basis for the acceptor stem recognition by ProRS is still unknown. Thus, for further studies it is necessary to obtain new crystals of the ProRSTT-tRNA ${ }^{\text {Pro }}$ 


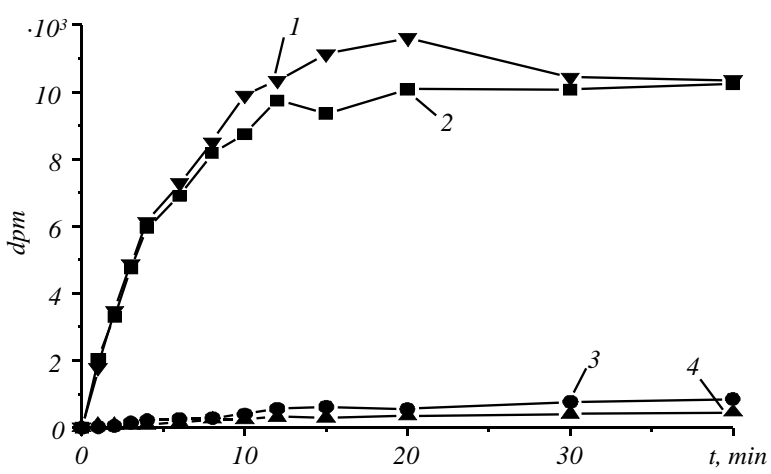

Fig. 4. Time-cours of aminoacylation of tRNA ${ }^{\text {Pro }}$ from different organisms by ProRSTT: 1 - E. coli; $2-T$. thermophilus; 3 - bovine; $4-$ yeast

complex in which the tRNA acceptor stem is bound to the catalytic site of the enzyme. The differences between two groups of ProRSs are of great interest from both the evolutionary and drug design points of view. Thus, the described here genetic construct for overexpression of T. thermophilus ProRS is important to develop our structural and functional studies in both directions.

Acknowledgements. We thank Dr. Stephen Cusack (EMBL Grenoble Outstation, France) for continued interest and support of this work.

\section{А. Д. Яремчук, К. С. Бояршин, М. А. Тукало}

Проліл-тРНК синтетаза із Thermus thermophilus є ферментом еукаріотичного типу, але аміноацилює прокаріотичну тРНК ${ }^{\text {Pro }}$

Резюме

Мета. Клонування, секвенування та експресія гена проліл-тРНК синтетази, ферменту IIа класу, з бактерії екстремального термофіла T. thermophilus HB8 (ProRSTT). Методи. Пошук гена Pro RSTT проводили методом Саузерн-блот-гібридизації з хромосомної ДНК, де як зонди використано мічені дигоксигеніном ПЛРфрагменти ДНК. Результати. Ген ProRSTT HB8 клоновано і секвеновано. Відкрита рамка зчитування гена кодуе білок довжиною 477 амінокислотних залишків, який має більщу гомологію з еукаріотичними і архейними, ніж з бактерійними ProRSs. Дані філогенетичного аналізу засвідчують, що існують дві різні структурні групи ProRS, які розійшлися на початку еволюції: 1) еукаріотично/архейний тип, що характеризується відсутністю вставки в області між мотивами 2 і 3 та наявністю додаткового С-кінцевого домену до звичайного для класу ІІа антикодон-зв'язувального домену та 2) прокаріотичний тип - з дуже великими вставками між мотивами 2 і 3 та без додаткового С-кінцевого домену. Висновки. 3 використанням експресуючого вектора ProRSTT суперпродуковано в клітинах Escherichia coli і термостабільний фермент очищено до високого ступеня гомогенності. Незважсючи на приналежність до еукаріотичного типу, ProRSTT показала здатність з високою специфічністю аміноацилювати бактерійну тРНК, у той час як активність відносно тРНК еукаріотів виявилася вкрай низькою.

Ключові слова: проліл-тРНК синтетаза з Thermus thermophilus, ген proS, клонування, секвенування, експресія.

\section{А. Д. Яремчук, К. С. Бояршин, М. А. Тукало}

Пролил-тРНК синтетаза из Thermus thermophilus является ферментом эукариотического типа, но аминоацилирует прокариотическую тPHK ${ }^{\text {Pro }}$

Резюме

Цель. Клонирование, секвенирование и экспрессия гена пролилтРНК синтетазы, фермента II класса, из бактерии экстремального термофила T. thermophilus HB8 (ProRSTT). Meтоды. Поиск гена ProRSTT проведен методом Саузерн-блот гибридизации с хромосомной ДНК, где в качестве зондов использованы меченные дигоксигенином ПЦР-фрагменты ДНК. Результаты. Ген ProRSTT HB8 был клонирован и секвенирован. Открытая рамка считывания гена кодирует белок длиной 477 аминокислотных остатков, который имеет большую гомологию с эукариотическими и архейными, чем бактериальными ProRSs. Данные филогенетического анализа показывают, что существуют две различные структурные группы ProRS, которые разошлись в начале эволюиии: 1) эукариотического/архейного типа, характеризующиеся отсутствием вставки в области между мотивами 2 и 3 и наличием дополнительного $C$-концевого домена к обычному для IIa класса антикодон связывающему домену и 2) прокариотического типа - с очень большими вставками между мотивами 2 и 3 и без дополнительного С-концевого домена. Выводы. С использованием экспресирующего вектора ProRSTT суперпродуцирована в клетках Escherichia coli и термостабильный фермент очищен до высокой степени гомогенности. Несмотря на свою принадлежность к эукариотическому типу, ProRSTT выявила способность аминоацилировать с высокой специфичностью бактериальную mPHК, в то время как активность по отношению к тРНК эукариотов оказалась крайне низкой.

Ключевые слова: пролил-тРНК синтетаза из Thermus thermophilus, ген proS, клонирование, секвенирование, экспрессия.

\section{REFERENCES}

1. Mazauric M. H., Reinbolt J., Lorber B., Ebel C., Keith G., Giege $R$., Kern D. An example of non-conservation of oligomeric structure in prokaryotic aminoacyl-tRNA synthetases. Biochemical and structural properties of glycyl-tRNA synthetase from Thermus thermophilus // Eur. J. Biochem.-1996.-241, N 3.-P. 814826.

2. Burke B., Yang F., Chen F., Stehlin C., Chan B., Musier-Forsyth $K$. Evolutionary coadaptation of the motif 2 - acceptor stem interaction in the class II prolyl-tRNA synthetase system // Biochemistry.-2000.-39, N 50.-P. 15540-15547.

3. Eriani G., Delarue M., Poch O., Gangloff J., Moras D. Partition of tRNA synthetases into two classes based on mutually exclusive sets of sequence motifs // Nature.-1990.-347, N 6289.P. 203-206.

4. Cusack S., Berthet-Colominas C., Hartlein M., Nassar N., Leberman $R$. A second class of synthetase structure revealed by X-ray analysis of Escherichia coli seryl-tRNA synthetase at $2.5 \mathrm{C} / /$ Nature.-1990.-347, N 6290.-P. 249-255.

5. Cusack S., Yaremchuk A., Krikliviy I., Tukalo M. tRNA(Pro) anticodon recgnition by Thermus thermophilus prolyl-tRNA synthetase // Structure.-1998.-6, N 1.-P. 101-108.

6. Yaremchuk A., Cusack S., Tukalo M. Crystal structure of a eukaryote/archaeon-like prolyl-tRNA synthetase and its complex with tRNAPr)(CGG) // EMBO J.-2000.-19, N 17.-P. 4745-4758. 
7. Beuning P. J., Musier-Forsyth K. Hydrolytic editing by a class II aminoacyl-tRNA synthetase // Proc. Natl Acad. Sci. USA.-2000.97, N 16.-P. 8916-8920.

8. Ahel I., Korencic D., Ibba M., Soll D. Trans-editing of mischarged tRNAs // Proc. Natl Acad. Sci. USA.-2003.-100, N 26.P. 15422-15427.

9. Liu H., Peterson R., Kessler J., Musier-Forsith K. Molecular recognition of tRNA(Pro) by Escherichia coli proline tRNA synthetase in vitro // Nucleic Acids Res.-1995.-23, N 1.-P. 165-169.

10. Stehlin C., Burke B., Yang F., Liu H., Shiba K., Musier-Forsyth $K$. Species-specific differences in the operational RNA code for aminoacylation of $\mathrm{tRNA}^{\text {Pro }} / /$ Biochemistry.-1998.-37, N 23.P. 8605-8613.

11. YaremchukA., Cusack S., Tukalo M. Crystallizaion and preliminary X-ray diffraction analysis of Thermus thermophilus prolyltRNA synthetase // Acta Crystallogr. D Biol. Crystallogr.-2000.56, N 1.-P. 195-196.

12. YaremchukA., Kriklivyi I., Cusack S., Tukalo M. Improved crystals of Thermus thermophilus prolyl-tRNA synthetase complexed with cognate tRNA obtained by crystallization from precipitate // Acta Crystallogr. D Biol. Crystallogr.-2000.-56, N 2.P.197-199.

13. Yaremchuk A., Tukalo M., Grotli M., Cusack S. A succession of substrate induced conformational changes ensures the amino acid specificity of Thermus thermophilus prolyl-tRNA synthetase: comparison with histidyl-tRNA synthetase // J. Mol. Biol.-2001.309, N 4.-P. 989-1002.

14. Crepin T., Yaremchuk A., Tukalo M., Cusack S. Structures of two bacterial prolyl-tRNA synthetases with and without a cis-editing domain // Structure.-2006.-14, N 10.-P. 1511-1525.
15. Oshima T., Imahori K. Physiochemical properties of deoxyribonucleic acid from an extreme thermophile // J. Biochem.-1974.75, N 1.-P. 179-183.

16. Sambrook J., Fritsch E. F., Maniatis T. Molecular cloning. A Laboratory manual.-New York: Cold Spring Harbor Lab. press, 1989.

17. Marmur J. A. Procedure for isolation of deoxyribonucleic acid from microorganisms // J. Mol. Biol.-1961.-3, N 2.-P. 208-218.

18. Sanger F., Nicklen S., Coulson A. R. DNA sequencing with chain-terminating inhibitors // Proc. Natl Acad. Sci. USA.1977.-74, N 12.-P. 5463-5467.

19. Taupin C. M., Leberman R. Archaebacterial seryl-tRNA synthetases: adaptation to extreme environments and evolutionary analysis // J. Mol. Evol.-1999.-48, N 4.-P. 408-420.

20. Muto A., Osawa S. The guanine and cytosine content of genomic DNA and bacterial evolution // Proc. Natl Acad. Sci. USA.1987.-84, N 1.-P. 166-169.

21. Shiba K., Motegi H., Schimmel P. Maintaining genetic code through adaptations of tRNA synthetases to taxonomic domains // Trends Biochem. Sci.-1997.-22, N 12.-P. 453-457.

22. Egorova S. P., Krikliviy I. A., Kovalenko O. P., Yaremchuk A. D., Tukalo M. A. Study on interaction of Thermus thermophilus prolyl-tRNA synthetase with gomologous tRNA $_{\mathrm{CGG}}$ Pro by methods of chemical modification in solution // Biopolym. Cell.2008.-24, N 5.-P. 385-392. 